\title{
OBTAINING RECOMBINANT EXTRACELLULAR FRAGMENTS OF GPR161 RECEPTOR
}

\author{
Kanaev D.B., Mukanov K.K., Adish Zh., Tokhtarova L., Zhumabekova S., \\ Inirbay B., Tursunov K.A., Ramankulov Ye.M., Mukantayev K.N. \\ National Center for Biotechnology \\ 13/5, Korgalzhyn road, Nur-Sultan, 010000, Kazakhstan \\ lii@biocenter.kz.
}

\section{ABSTRACT}

The GPR161 is a receptor of the GPCR family and identified as a prognostic biomarker for triple negative breast cancer (TNBC). TNBC characterized by lack of expression of the estrogen receptor (ER), progesterone receptor (PR) and epidermal growth factor receptor (Her2), early recurrence and poor prognosis. The GPR161 is an important regulator of the proliferation and migration of cancer cells. However, anti-GPCR receptor drugs are rarely used in the treatment of cancer, despite evidence of receptor involvement in various aspects of cancer development. Upon receipt of monoclonal antibodies, the success of the study is associated with the presence in sufficient quantities of pure antigen preparations. Recently, gene synthesis under de novo conditions has become a powerful tool in biotechnology. A number of methods have been described, representing thermodynamic balanced methods based on polymerase chain reaction (PCR). This paper presents the results of gene synthesis and the preparation of a recombinant extracellular fragment of the receptor.

To obtain a recombinant protein, an area located outside the cell membrane between the 4th and 5th helix of the receptor was selected. A genetic construct based on the pET32 vector carrying the extracellular fragment of the human GPR161 receptor has been developed and obtained. Strain Escherichia coli BL21/pET32/TM4-5GPR161 producing recombinant extracellular fragment rTM45 GPR161 was obtained. The conditions for the isolation and purification of recombinant protein were determined, and its immunogenic properties were studied.

Purified recombinant protein TM4-5GPR161 in its immunological characteristics suitable for the production of strains of hybrid cells producing monoclonal antibodies to the GPR161 receptor.

Keywords: GPCR, GPR161, receptor, breast cancer, genetic construction, recombinant protein.

\section{INTRODUCTION}

The GPR161 receptor is representative of GPCR family and is not well characterized regarding the regulation of cancer cell oncogenesis. The studies described in the literature demonstrate an important role of the GPR161 receptor only in the process of normal cell development. In some studies, it was noted that GPR161 is part of the signal network, providing resistance to inhibition of the MAP-kinase signaling pathway in melanoma [1]. 
Feigin M.E. et al. (2014), identified the GPR161 receptor as a prognostic biomarker for triple negative breast cancer (TNBC) and an important regulator of the proliferation and migration of cancer cells [2]. TNBC characterized by the absence of expression of the estrogen receptor (ER), progesterone receptor (PR) and epidermal growth factor receptor (Her2), early recurrence and poor prognosis [3, 4, 5]. GPR161 receptor, like all receptors of this family, transforms the signals of extracellular ligands across the plasma membrane, modulating the intracellular signaling pathways. The receptor is involved in the activation of the mTORC1/S6K signaling pathway by reducing the phosphorylation of IQGAP1 [6].

Transformation of extracellular ligand signals is achieved to a significant degree by activating heterotrimeric G-proteins and processing secondary intermediate proteins. The receptor consists of seven transmembrane spirals that regulate a variety of physiological processes, including vision, smell, taste, behavior, and signaling in the autonomic nervous system. The wide range of receptor functions has contributed to the widespread use of GPCR as targets in the treatment of many diseases. The result of the extensive use of drugs based on GPCR is also localization of receptors on the cell surface and their ability to bind a variety of ligands, including antibodies, peptides and small molecules [7].

However, anti-GPCR receptor drugs are rarely used in cancer treatment despite evidence of involvement in various aspects of cancer development. Modern studies have shown that such mutations in the receptor genes as a change in the number of copies and expression, as well as a change in their methylation, were detected in some cancer diseases [8].

At the obtaining of monoclonal antibodies, the success of the study is associated with the presence in sufficient quantities of pure antigen preparations. The main difficulty in obtaining membrane proteins of eukaryotic cells is their low concentration, the use of expensive and timeconsuming methods of isolation. Because of the limitations in obtaining target surface molecules from native tissues and cells, recombinant forms of receptor and ligand proteins are often the preferred choice for research. Most often, bacteria are used to express recombinant proteins, as they are economical in terms of cost, speed, and ease of use. These approaches are commonly used to obtain many cell surface receptors and ligand proteins with intact native structures and active functions. [9].

Recently, gene synthesis under de novo conditions has become a powerful tool in biotechnology. Chemical synthesis of DNA sequences ensures the optimization of genes to achieve efficient gene expression in heterologous systems, as well as the study of the characteristics of the structure, expression, and function of the gene. In recent years, a number of oligonucleotide methods for the synthesis and assembly of DNA sequences have been described [10].

Based on literature data on the production of recombinant receptors of the GPRR family in heterogeneous systems $[11,12,13]$, we used E. coli bacteria to produce the extracellular fragment of the GPR161 receptor. This paper presents the results of studies on the synthesis of the receptor extracellular fragment in de novo conditions. Expression parameters that affect protein yield and the results of isolation and purification of the target product are described.

\section{Materials and methods}

Bacterial strains, plasmids, and antibodies. E. coli DH5 $\alpha$, BL21 (DE3) (Novagen, USA) strains, pGEM-TEasy (Promega, USA) and pET32 (Novagen, USA) plasmid vectors were used. Cultivation of $E$. coli cells was perforemed using LB and 2xYT media. For immunoblot, mouse anti-His-tag monoclonal antibodies and peroxidase-conjugated anti-antibodies were used (Sigma-Aldrich, Germany). To synthesize the gene sequence of the coding extracellular fragments of the human GPR161 receptor, the amino acid sequence from the PubMed NCBI Reference Sequence database was used: isoform 2 receptors, No. NP_001254538.1.

Genetic construct. Gene synthesis was performed by a two-round polymerase chain reaction using Phusion High-Fidelity DNA Polymerase polymerase (Thermo Fisher Scientific). 
For preparative production and sequencing, the synthesized genes were cloned into the pGEMTEsy vector. Then, the synthesized genes at the NcoI and XhoI restriction sites were cloned into the expression plasmid pET32 (Invitrogen).

Transformation and expression of recombinant extracellular fragments of the GPR161 receptor. The transformation of competent cells E. coli BL21 (DE3) with pET32 vector carrying gene insert was performed by electroporation using MicroPulser (BioRad). Transformed cells were cultured on LB agar medium with ampicillin at $37^{\circ} \mathrm{C}$ for 16 hours. The obtained colonies were screened by PCR using a Tag DNA Polymerase (Thermo Fisher Scientific) and $\mathrm{T} 7$ primers.

Single colonies of transformants were cultured in $5 \mathrm{ml}$ of LB medium containing $2 \%$ glucose and ampicillin. Cells were incubated at $37^{\circ} \mathrm{C}$ for 12 hours with constant stirring at 160 $\mathrm{rpm}$. The cell suspension was transferred to $50 \mathrm{ml}$ of $2 \mathrm{xYT}$ medium containing $0.2 \%$ glucose and ampicillin in $250 \mathrm{ml}$ flasks and cultured at $37^{\circ} \mathrm{C}$ under constant aeration at $160 \mathrm{rpm}$. Upon reaching a density of $\mathrm{OD}_{600}-0.35$, the cell suspension was cooled and cultured at $20^{\circ} \mathrm{C}$ at 160 rpm to OD600 - 0.5. After reaching the required optical density, an inducer, isopropyl- $\beta$-D-1galactopyranoside (IPTG), was introduced into the cell suspension at a final concentration of 0.1 $\mathrm{mM}$. Within 24 hours of cultivation, at the control time points of 2, 6, 20, and 24 hours, $10 \mathrm{ml}$ of medium were selected for determination of protein expression. The collection of cells carried out by centrifugation at $+4^{\circ} \mathrm{C}, 6000 \mathrm{~g}$ for 7 minutes. The cell pellet was dissolved in buffer $(20 \mathrm{mM}$ $\mathrm{NaCl}, 20 \mathrm{mM}$ Hepes $\mathrm{pH} 7.5$ ), lysozyme was added to a concentration of $1 \mathrm{mg} / \mathrm{ml}$ and incubated on ice for 30 minutes. The resulting samples were sonicated and analyzed by electrophoresis according to U.K. Laemmli [14] and Western blot.

Cell lysis and chromatography purification of the recombinant extracellular fragment of GPR161 receptor. For purification of the recombinant extracellular fragment of the GPR161 receptor, $5 \mathrm{ml}$ of an overnight culture of E. coli BL21/pET32/TM4-5 GPR161 strains were added to $500 \mathrm{ml}$ of 2xYT medium containing $1 \%$ glucose and ampicillin. Induction of expression of recombinant extracellular receptor fragments was performed with $0.1 \mathrm{mM}$ IPTG for 24 hours at $20^{\circ} \mathrm{C}$, as described above. For purification of recombinant proteins, the cells were precipitated by centrifugation, the pellet was dissolved with buffer $(20 \mathrm{mM} \mathrm{NaCl}, 20 \mathrm{mM}$ Hepes pH7.5) containing lysozyme $(1 \mathrm{mg} / \mathrm{ml})$ and PMSF. Cell lysis was performed using a UP200S ultrasonic disintegrator at a frequency of $24 \mathrm{kHz}$ in a pulsating mode (10 pulses, $10 \mathrm{~s} / \mathrm{pulse})$ on ice. Protein purification was performed by metal-chelate chromatography on $\mathrm{Ni} 2+$ ions using a HisTrapTM HP $1 \mathrm{ml}$ column (GE Healthcare). The equilibration and loading of the lysate were performed according to the manufacturer's protocol. To determine an optimal concentration of imidazole for elution, an imidazole step gradient with initial buffer $(500 \mathrm{mM} \mathrm{NaCl}, 20 \mathrm{mM}$ Hepes pH-7.5, $2 \mathrm{M}$ urea, $20 \mathrm{mM}$ imidazole) and final buffer $(500 \mathrm{mM} \mathrm{NaCl}, 20 \mathrm{mM}$ Hepes pH7.5, $2 \mathrm{M}$ urea, $400 \mathrm{mM}$ imidazole) was used. The protein concentration in the lysate and fractions was determined by Bradford using bovine serum albumin as a standard [15].

Western blot. Electrophoresis of recombinant GPR161 was performed on an $11 \%$ polyacrylamide gel in the presence of sodium dodecyl sulfate (SDS) according to the U.K. Laemmli method on the apparatus for vertical electrophoresis (BioRad, USA) [14]. Electrophoretic transfer of antigens from the gel to the nitrocellulose membrane was performed using an immunoblotting device (BioRad, USA) according to the method of P.K. Towbin [16].

For the immunochemical manifestation of specific antigens, the nitrocellulose membrane was first incubated in $1 \% \mathrm{BSA}$ solution overnight at $4^{\circ} \mathrm{C}$. Then it was washed three times in buffer (137 mM NaCl, $\left.10 \mathrm{mM} \mathrm{Na} \mathrm{m}_{2} \mathrm{HPO} 4, \mathrm{pH}-7.4\right)$ and buffer (137 mM NaCl, $10 \mathrm{mM} \mathrm{Na} 2 \mathrm{HPO} 4$, $\mathrm{pH}-7.4$, Tween-20) and kept for 1.5 hours at $37^{\circ} \mathrm{C}$ in a solution of monoclonal antibodies purified from ascites fluid, at a dilution of 1: 100 in a buffer $(137 \mathrm{mM} \mathrm{NaCl}, 10 \mathrm{mM} \mathrm{Na} 2 \mathrm{HPO} 4$, $\mathrm{pH}-7.4$, Tween-20). After that, the carrier was washed again and incubated in a working dilution of anti-peptide antibodies labeled with peroxidase for 1 hour at $37^{\circ} \mathrm{C}$, and the washing procedure was repeated. The substrate solution was prepared immediately before use as follows: $0.01 \mathrm{~g}$ of 
4-chloro-naphthol (Sigma, USA), dissolved in $2 \mathrm{~mL}$ of ethanol, mixed with $18 \mathrm{~mL}$ of buffer (137 $\mathrm{mM} \mathrm{NaCl}, 10 \mathrm{mM} \mathrm{Na} 2 \mathrm{HPO} 4, \mathrm{pH}-7.4)$ and $0.01 \mathrm{~mL}$ of $3 \%$ hydrogen peroxide was added.

Immunization of mice. Mice on the first day of immunization were injected intraperitoneally with $100 \mu \mathrm{g}$ of antigen in $0.1 \mathrm{~mL}$ of Freund's incomplete adjuvant (Gibco, USA). On days 7, 11, 12, 13 of immunization, animals were injected with $100 \mu \mathrm{g}$ of antigen in phosphate-buffered saline, $\mathrm{pH}$ 7.2-7.4. Three days after the last immunization, the serum of the immunized mice was tested for the presence of antibodies to the recombinant Trx-PD-1 protein by enzyme immunoassay.

ELISA. The immunological plate was immobilized by diluting the antigen at a concentration of $10 \mu \mathrm{g} / \mathrm{mL}$. The antigen was diluted in $\mathrm{pH}-9.5$ bicarbonate buffer and incubated at $+4^{\circ} \mathrm{C}$ for 12 hours. After incubation, the plate was washed 4 times with a solution of the phosphate-saline buffer with Tween-20, $\mathrm{pH}-7.2$. The free surface of the plate was filled with a $10 \%$ solution of skimmed milk in phosphate-saline buffer + tween-20, pH-7.2. The plate with blocking solution was incubated at $37^{\circ} \mathrm{C}$ for 1 hour and washed as above.

Prepared dilutions of the studied and control sera were added to the wells of an immunological plate in a volume of $0.1 \mathrm{~mL}$. Wells E12 and $\mathrm{H} 12$ were left without serum as conjugate control. The plate was incubated for 1 hour at $37^{\circ} \mathrm{C}$ and the washing procedure was repeated. A working dilution of the anti-species conjugate in a volume of $0.1 \mathrm{~mL}$ was added to all wells of the plate, except the well $\mathrm{H} 12$ (blank), and incubated for 1 hour at $37^{\circ} \mathrm{C}$. A working dilution of the conjugate was prepared by adding to $10 \mathrm{~mL}$ of phosphate-saline buffer + tween20, $\mathrm{pH}-7.2,1 \mu \mathrm{L}$ of Anti-Bovine IgG conjugate (whole molecule) - Peroxidase antibody produced in rabbit (Sigma, USA). The plate was washed 3 times with phosphate-saline buffer + tween-20, pH-7.2 and 3 times with distilled water. After washing, $0.1 \mathrm{~mL}$ solution of tetramethylbenzidine (TMB) was added. The plate was incubated in a dark place at room temperature $\left(20-22^{\circ} \mathrm{C}\right)$ for 15 minutes. The reaction was stopped by adding $0.1 \mathrm{~mL}$ of $2 \mathrm{M}$ sulfuric acid. The results of the reaction were taken into account on a spectrophotometer at a wavelength of $492 \mathrm{~nm}$.

\section{RESULTS}

Obtaining of the genetical construction pET32/TM4-5GPR161. Based on data from the structural organization of the GPRC receptors family, the sequence located outside of cell membrane was selected. Selected site was designated as TM4-5 GPR161 receptor. TM4-5 refers to the extracellular fragment of the receptor located between 4 and 5 transmembrane receptor helices. The amino acid sequence of the selected extracellular fragment of the GPR161 receptor is shown in figure 1 .

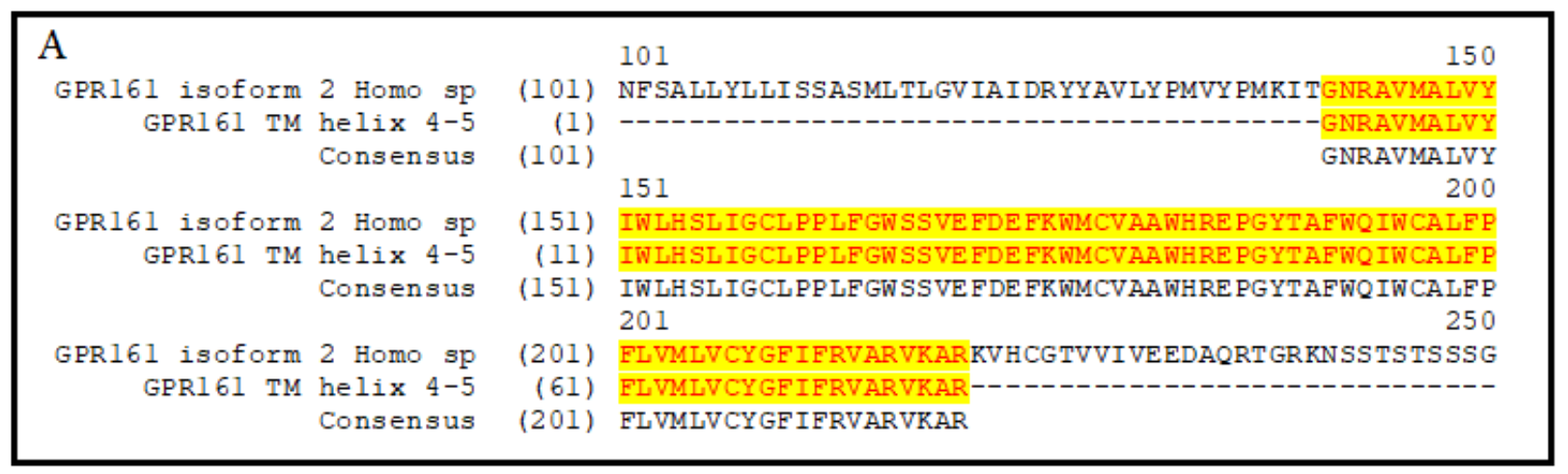

Fig.1. The amino acid sequence of extracellular fragments of the GPR161 receptor between 4 and 5 helices

As a result of this work, a genetic construct was developed based on the pET32 vector that carries the human extracellular fragment of the GPR161 receptor gene (Figure 2). The GPR161 receptor extracellular fragment gene is inserted into the pET32 vector by the NcoI and XhoI 
restriction sites. The expression region of the plasmid vector pET32 together with the inserted gene includes the thioredoxin gene, 6His-Tag, the gene for the extracellular fragment of the human GPR161 receptor and 6His-Tag. The predicted molecular weight of the recombinant protein is $25 \mathrm{kDa}$

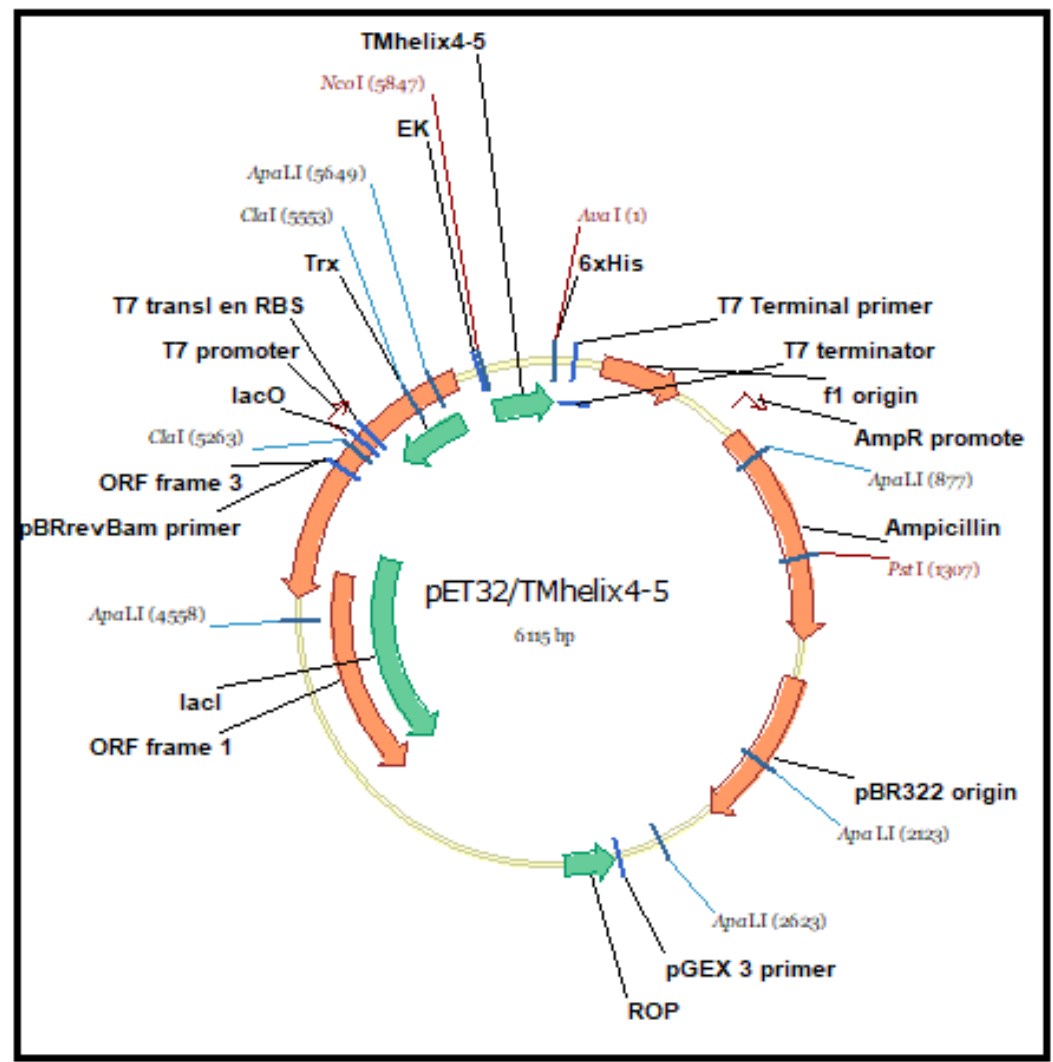

Fig.2. Genetic construct of the pET32/TM4-5 GPR161 receptor containing the extracellular fragment of the GPR161 receptor

For the synthesis of genes of the extracellular fragments of the GPR161 receptor, a twostage PCR was used. The meaning of the first stage of PCR was to assemble the gene from mutually overlapping gene fragments synthesized under de novo conditions. The second stage using the end primers "start" and "stop" amplified the resulting gene. As a result of PCR, DNA product was obtained with a length of 266 base pairs. The DNA sequencing of the synthesized gene of the extracellular fragment of the GPR161 receptor did not reveal substitutions or deletions in the nucleotide sequence. In accordance with the genetic construct, the human GPR161 receptor extracellular fragment has been cloned into the expression plasmid pET32 at the NcoI and XhoI restriction sites.

Transformation and production of an $E$. coli strain producing rTM4-5GPR161. Experiments with the transformation of genetic constructs allowed us to obtain the E. coli strain BL21/pET32/TM4-5GPR161 producing a recombinant extracellular fragment rTM4-5 GPR161. Colony screening by PCR revealed the presence of the genetic construct pET32/TM4-5 GPR161 in the transformants.

Determination of the productivity of the obtained microbial strains showed that the cells produce a protein with a molecular weight of $25 \mathrm{kDa}$ corresponding to the molecular mass of rTM4-5 GPR161 (Figure 3A). A Western blot with antibodies against a hexa-histidine tag showed the presence of a protein with a molecular weight corresponding to the recombinant TM4-5 GPR161 protein (Figure 3B). 

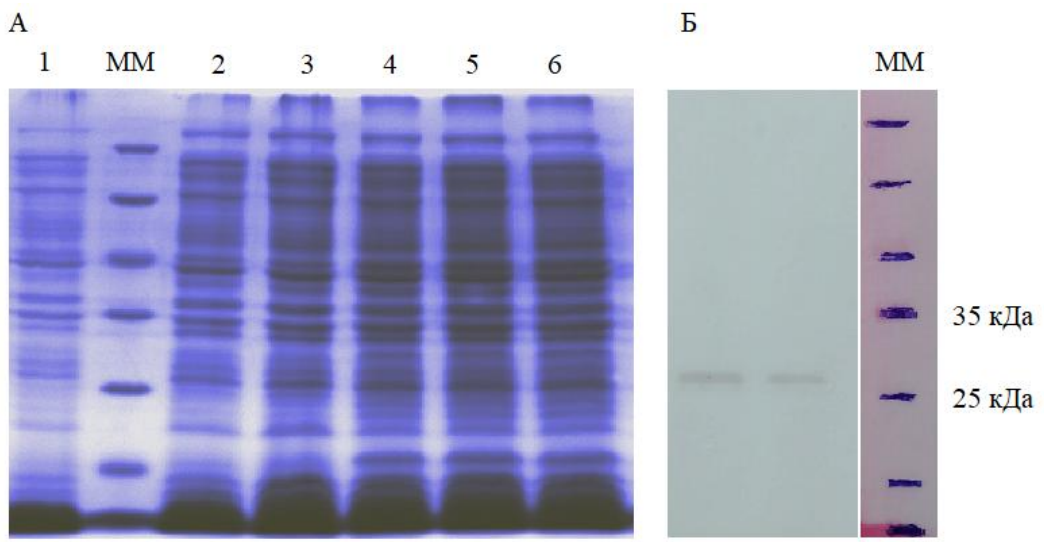

1 - without IPTG; 2 - 2 hours with IPTG; 3 - 4 hours with IPTG; 4 - 12 hours with IPTG; 5 - 20 hours with IPTG; 6 - 24 hours with IPTG; MM - molecular markers.

Fig. 3. PAAG electrophoresis (A) and Western blot (B) of the extracellular fragment of the GPR161 receptor expressed by BL21/pET32/TM4-5-5.

Isolation and purification of recombinant TM4-5GPR161. To optimize the isolation and purification of the recombinant TM4-5 GPR161 protein, the producer strains were cultivated under various temperature conditions and various inducer concentrations: $0.1 \mathrm{mM}, 0.25 \mathrm{mM}, 0.5$ $\mathrm{mM}, 1 \mathrm{mM}$. The results of the experiment were evaluated by the relative content of recombinant proteins in the insoluble fraction of the lysates of the producer strain. Studies have shown that for all strains-producers selected for further work, the maximum production of recombinant proteins in the soluble fraction was observed under the following cultivation conditions: inducer concentration $0.1 \mathrm{mM}$, cultivation temperature after induction of expression $-25^{\circ} \mathrm{C}$.

An important step in purification is determining the location of the protein and the processing conditions to extract the protein from the inclusion bodies. For this, the destroyed cells were treated with various concentrations of urea. As a result, it was found that the recombinant protein remains in the supernatant and effectively releases by adding $2 \mathrm{M}$ urea in a buffer (data not shown).

As a result of testing the parameters for the isolation and purification of recombinant protein, purified preparations of antigens were obtained. Nickel-sepharose-based metal chelate chromatography was used to purify the recombinant protein. A buffer containing $400 \mathrm{mM}$ imidazole was used as elution buffer. The electrophoretic analysis showed pure preparations of extracellular fragments of the human GPR161 receptor with a molecular mass of $25 \mathrm{kDa}$ based on the plasmid pET32 (Figure 4).

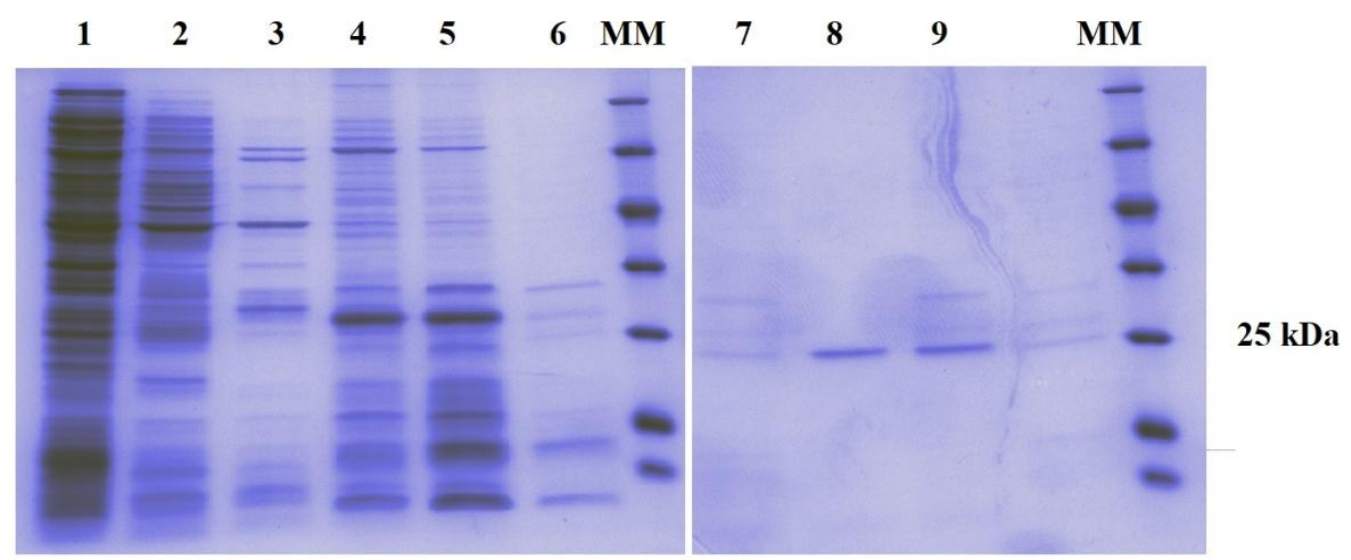

1 - flow through; 2 - wash; 3 to $50 \mathrm{mM}$ imidazole; 4-5-100 mM imidazole; 6 to $150 \mathrm{mM}$ imidazole; 7 - 200 mM imidazole; 8-9 - 400 mM imidazole; MM - molecular marker. 
Fig.4. PAAG electrophoresis purification of recombinant TM4-5GPR161 protein

The immunogenic properties of the recombinant extracellular fragment of the TM45 GPR161 receptor. To determine the immunogenic properties of rTN4-5GPR161, laboratory white mice were used, divided into 3 groups of 3 heads weighing $18-20 \mathrm{~g}$. The first group of mice was immunized with recombinant protein at a concentration of $100 \mu \mathrm{g} / \mathrm{ml}$, group $2-50$ $\mu \mathrm{g} / \mathrm{ml}$ and group $3-25 \mu \mathrm{g} / \mathrm{ml}$. Freund's incomplete adjuvant (NAF) was used as an immune response enhancer. Upon completion of immunization in laboratory mice, blood was collected through the tail vein and examined by enzyme immunoassay.

As a result of the analysis of the sera from immunized mice, sufficiently high immunogenicity of the recombinant TM4-5GPR161 protein was detected. At a 1:100 dilution of serum, the average optical density was $0.800-1.200$, depending on the dose administered. At serum dilution of 1:3200, the optical density of the reaction, twice the negative control, was observed only in serum with an immunized dose of $100 \mu \mathrm{g} / \mathrm{ml}$. At the same time, these results were obtained when diluting sera to titer 1:12800 (Figure 5).

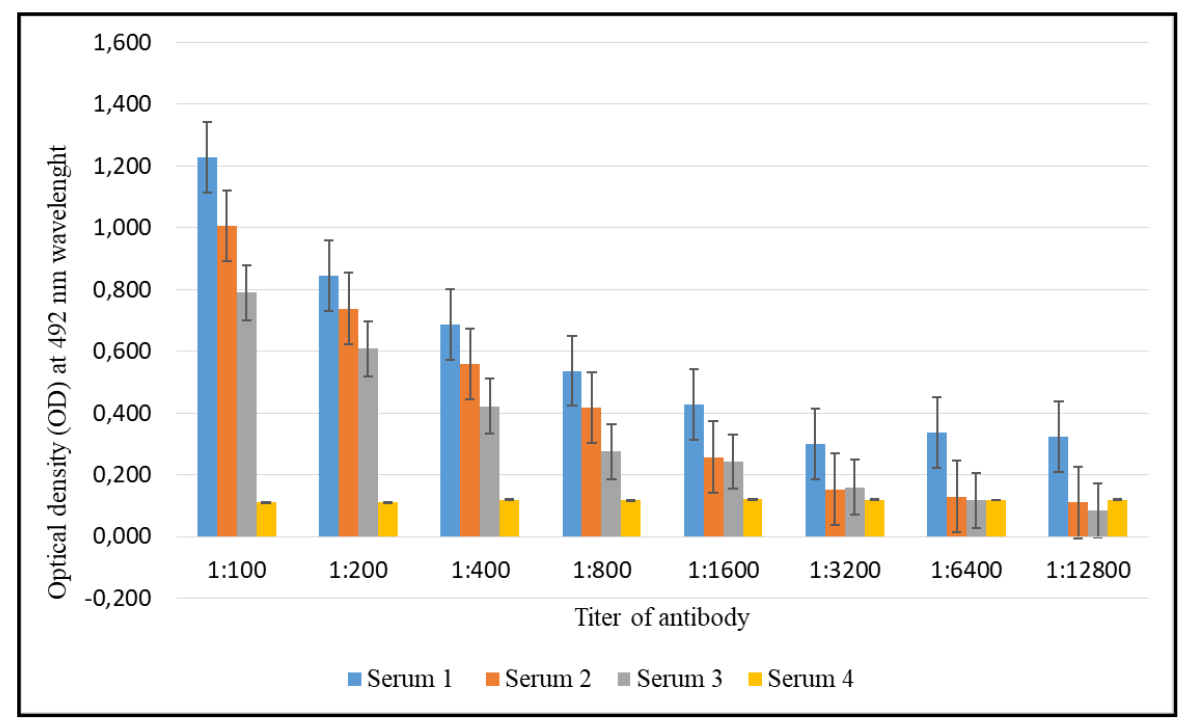

Serum 1 - mouse immunized with protein at a concentration of $100 \mu \mathrm{g} / \mathrm{mL}$; Serum 2 - mouse immunized with proteins at a concentration of $50 \mu \mathrm{g} / \mathrm{mL}$; Serum 3 - mouse immunized with protein at a concentration of 25 $\mu \mathrm{g} / \mathrm{mL}$; Serum 4 - not immunized mouse.

Fig.5. Diagram of ELISA of mice serum immunized with recombinant TM4-5 GPR161 protein.

\section{DISCUSSION}

The GPR161 receptor is a prognostic biomarker for triple negative lactic acid cancer and an important regulator of the proliferation and migration of breast cancer cells. It was found that the GPR161 receptor is over-expressed only in TNBC cells and correlates with a poor prognosis. The authors identify GPR161 as a regulator of proliferation and invasion of epithelial cells of the mammary gland associated with the signal pathway of rapamycin [2]. Thus, the production of the GPR161 receptor in the form of recombinant proteins is a very topical issue.

Given the importance of the GPR161 receptor in the diagnosis and therapy of triple breast cancer, the gene for the extracellular fragment of the GPR161 receptor was synthesized de novo and cloned into the pET32 plasmid. For the study, a receptor fragment located between the 4th and 5th spirals was used, therefore it is designated as rTM4-5GPR161. As a result of the transformation of the genetic construct into E. coli strain BL21, a strain of the microorganism $E$. coli BL21/pET32/TM4-5GPR161 was obtained, producing an extracellular fragment of the GPR161 receptor. 
There is currently no universal recombinant expression strategy for high-level GPR161 functional receptors. Some GPCRs accumulate in the membrane to high levels, while others often close receptors are hardly detectable. Despite their perceived similarities, individual GPCRs behave differently in one expression, and recombinant production is still a matter of trial and error. For example, comparative studies of expression were carried out using the methylotrophic yeast Pichia pastoris, the baculovirus-insect cell system and the Semliki Forest virus system $[17,18]$.

Among the many systems available for heterologous protein, the products of Gramnegative bacteria $E$. coli remain one of the most attractive hosts. However, despite extensive knowledge of genetics and molecular biology of $E$. coli, not every gene can be effectively expressed [19]. Using eukaryotic hosts is generally better for creating functional GPCRs inserted into the membrane than for prokaryotic hosts, although there are exceptions. However, on the basis of E. coli, strains of microorganisms that produce recombinant receptors of this family have been successfully obtained [20, 21, 22].

Analysis of the immunogenicity of the obtained recombinant TM4-5GPR161 showed that the obtained recombinant possesses high immunogenic activity. In mice immunized with recombinant protein, a high titer of specific antibodies was formed, confirming a high concentration of stimulated B-lymphocytes

\section{CONCLUSION}

As a result of the studies carried out under de novo conditions, the gene of the extracellular fragment of the TM4-5GPR161 receptor was synthesized and cloned into the plasmid pEE32. The resulting genetic construct was transformed into strain E. coli BL21. Purified recombinant TM4-5GPR161 protein, by its immunological characteristics, is suitable for producing strains of hybrid cells producing monoclonal antibodies to GPR161 receptor.

\section{Acknowledgments}

This research was supported by Ministry of Education and Science of the Republic of Kazakhstan (grant AP05130053 «Obtaining monoclonal antibodies to GPR161 a marker of metastatic breast cancer», 2018-2020).

\section{REFERENCES}

1. Johannessen C.M., Johnson L.A., Piccioni F., Townes A., Frederick D.T., Donahue M.K., Narayan R., Flaherty K.T., Wargo J.A., Root D.E., Garraway L.A. A melanocyte lineage program confers resistance to MAP kinase pathway inhibition. Nature, 2013, vol. 504. pp. 138142. doi: 10.1038/nature12688.

2. Feigin M.E., Bin Xuea, Hammella M.C., Muthuswamya S.K. G-protein-coupled receptor GPR161 is overexpressed in breast cancer and is a promoter of cell proliferation and invasion. Proceedings of the National Academy of Sciences, 2014, vol. 111, no. 11, pp. 4191-4196. doi: 10.1073/pnas.1320239111.

3. Lachapelle J., Foulkes W.D. Triple-negative and basal-like breast cancer: implications for oncologists. Current Oncology, 2011, vol. 18, no. 4, pp. 161-164. doi: 10.3747/co.v18i4.824.

4. Foulkes W.D., Smith I.E., Reis-Filho J.S. Triple-negative breast cancer. The New England Journal of Medicine, 2010, vol. 363, pp. 1938-1948. doi: 10.1056/NEJMra1001389.

5. Rakha E., Reis-Filho J.S. Basal-like breast carcinoma: from expression profiling to routine practice. Archives of Pathology \& Laboratory Medicine, 2009, vol. 133, pp. 860-868. doi: 10.1043/1543-2165-133.6.860.

6. Skovorodnikova P.A., Chesnokov M.S., Budko A.A., Kustova I.F., Lazarevich N.L. IQGAP scaffold proteins are the multifunctional regulators of cellular signaling and malignant 
transformation. Advances in molecular oncology, 2017, vol. 4, pp. 36-45. doi: 10.17650/2313805X-2017-4-2-36-45.

7. Michael E. Feigin. Harnessing the genome for characterization of G-protein coupled receptors in cancer pathogenesis. FEBS Journal, 2013, vol. 280, pp. 4729-4738. doi: 10.1111/febs. 12473.

8. Kan Z., Jaiswal B.S., Stinson J., Janakiraman V., Bhatt D.,Stern H.M., Yue P., Haverty P.M., Bourgon R., Zheng J. Diverse somatic mutation patterns and pathway alterations in human cancers. Nature, 2010, vol. 466, pp.869-873. doi: 10.1038/nature09208.

9. Zhai L., Wu L., Li F., Burnham R.S., Pizarro J.C., Xua B. A Rapid Method for Refolding Cell Surface Receptors and Ligands. Scientific Reports, 2016, vol. 6, pp. 26482-26491. doi: 10.1038/srep26482.

10. Xiong A.S., Yao Q.H., Peng R.H., Duan H., Li X., Fan H.Q., Cheng Z.M., Li Y. PCRbased accurate synthesis of long DNA sequences. Nature Protocols, 2006, vol. 1, no. 2, pp. 791797. doi: 10.1038/nprot.2006.103.

11. Andre N., Cherouati N., Prual C., Steffan T., Zeder-lutz G., Magnin Th., Pattus F., Michel H., Wagner R., Reinhart Ch. Enhancing functional production of $\mathrm{G}$ protein-coupled receptors in Pichia pastoris to levels required for structural studies via a single expression screen. Protein Science, 2006, vol. 15. pp. 1115-1126. doi: 10.1110/ps.062098206.

12. Attrill H., Harding P.J., Smith E., Ross S., Watts A. Improved yield of a ligand-binding GPCR expressed in E. coli for structural studies. Protein Expression and Purification, 2009, vol. 64, pp. 32-38. doi: 10.1016/j.pep.2008.10.001.

13. Petrovskaya L.E., Shulga1 A.A., Bocharova O.V., Ermolyuk Ya.S., Kryukova E.A., Chupin V.V., Blommers M.J.J., Arseniev A.S., Kirpichnikov M.P. Expression of G Protein Coupled Receptors in Escherichia coli for Structural Studies. Biochemistry, 2010, vol. 75, pp. 881-891. doi: 10.1134/S0006297910070102.

14. Laemmli U. K. Cleavage of structural proteins during the assembly of the head of bacteriophage T4. Nature, 1970, vol. 227, pp. 680-685. doi: 10.1038/227680a0.

15. Bradford M. A rapid and sensitive method for the quantitation of microgram quantities of protein utilizing the principle of protein - due binding. Analytical Biochemistry, 1976. vol. 72, pp. 248-254. doi.org/10.1016/0003-2697(76)90527-3.

16. Towbin P.K., Strahelin T., Gordon J. Electrophoretic transfer of proteins from polyacrylamide gels to nitrocellulose sheets. Proceeding National Academic Science USA, 1979, vol. 76, pp. 4350-4354. doi: 10.1073/pnas.76.9.4350.

17. Akermoun M., Koglin M., Zvalova-Iooss D., Folschweiller N., Dowell S.J., Gearing K.L. Characterization of 16 human $G$ protein-coupled receptors expressed in Baculovirusinfected insect cells. Protein Expression and Purification, 2005, vol. 44. pp. 65-74. doi:10.1016/j.pep.2005.04.016.

18. Hassaine G., Wagner R., Kempf J., Cherouati N., Hassaine N., Prual C., Andre N., Reinhart C., Pattus F., Lundstrom K. Semliki Forest virus vectors for overexpression of $101 \mathrm{G}$ protein-coupled receptors in mammalian host cells. Protein Expression and Purification, 2006, vol. 45, pp. 343-351. doi: 10.1016/j.pep.2005.06.007.

19. Sivashanmugam A., Murray V., Cui Ch., Zhang Y., Wang J, Li Q. Practical protocols for production of very high yields of recombinant proteins using Escherichia coli. Protein science, 2009, vol. 18, pp. 936-948. doi: 10.1002/pro.102.

20. Grisshammer R., Duckworth R., Henderson R. Expression of a rat neurotensin receptor in Escherichia coli. Biochemical Journal, 1993, vol. 295, pp. 571-576. doi: 10.1007/s10969-0051917-6.

21. White J.F., Trinh L.B., Shiloach J., Grisshammer R. Automated large-scale purification of a G-protein-coupled receptor for neurotensin. FEBS Letters, 2004, vol. 564, pp. 289-293 doi: 10.1016/S0014-5793(04)00195-4. 
22. Yeliseev A.A., Wong K.K., Soubias O., Gawrisch K. Expression of human peripheral cannabinoid receptor for structural studies. Protein Science, 2005, vol. 14, pp. 2638-2653. doi: 10.1110/ps.051550305.

\title{
GPR161 РЕЦЕПТОРЫНЫҢ РЕКОМБИНАНТТЫ ЖАСУШАДАН ТЫС ФРАГМЕНТТЕРІН АЛУ
}

Қанаев Д.Б., Мұқанов Қ.Қ., Әдіш Ж.Б., Тохтарова Л.Т., Жұмабекова С., Інірбай Б.К., Турсунов К.А., Раманқұлов Е.М., Мұқантаев К.Н.

\author{
Ұлттық биотехнология ортальвы \\ 13/5, Қорвалжын тас жоль, Нұр-Сұлтан, 010000, Қазақстан \\ lii@biocenter.kz.
}

\section{ТYЙІН}

GPR161 GPCR тобының рецепторы болып табылады және (TNBC) үштік негативтік сүт безі ісігінің болжамдық биомаркері ретінде сәйкестендірілген. TNBC (ER) эстраген рецепторының, (PR) прогестерон рецепторының және (Her2) эпидермалды өсу факторы рецепторының ерте рецедив және жаман болжамдардын болмауымен сипатталады. GPR161 ісік жасушаларының пролиферациясы мен миграциясының маңызды реттеушісі болып табылады. Ісіктің дамуының әртүрлі аспектілерінде рецепторлар қатысының бар екені дәлелденгеніне қарамастан, GPCR қарсы рецепторлық препараттар ісікті емдеуде көбіне қолданылмайды. Моноклоналды антиденелерге қол жеткізу кезінде жақсы нәтиже таза антигендік препараттардың кажетті мөлшерде болуымен байланысты. Соңғы уақытта de novo жағдайында гендерді синтездеу биотехнология саласында маңызды құралдардың біріне айналды. ПТР полимеразды тізбекті реакцияға негізделген термодинамикалық тендестірілген әдістердің бірнешеуі сипатталды. Бұл жұмыста гендердің синтезінің және рецептордың рекомбинантты жасушадан тыс фрагменті дайындалуының нәтижелері ұсынылған.

Рекомбинантты ақуыздарға қол жеткізу үшін 4-ші және 5-ші рецепторлық спираль арасындағы жасушадан тыс орналасқан мембраналар аймағы таңдап алынды. GPR161 адам рецепторының жасушадан тыс орналасқан фрагментінің тасымалдаушысы ретінде рЕT32 векторы негізіндегі генетикалық конструкцияға қол жеткізілді. Escherichia coli BL21 / pET32 / TM4-5GPR161 штаммы алынды, rTM4-5 GPR161 рекомбинантты жасушадан тыс фрагменттері өнделді. Рекомбинантты ақуызды бөліп алу және тазарту үшін жағдай анықталды және оның иммуногенді қасиеттері зерттелді.

Тазартылған TM4-5GPR16 рекомбинантты ақуыз өзінің иммунологиялық сипаттамалары бойынша GPR161 рецепторы үшін моноклоналды антиденелер түзетін жасушалар гибридті жасушалар штаммдарын түзуге жарамды деп танылды.

Негізгі сөздер: GPCR, GPR161, рецептор, сүт безі қатерлі ісігі, генетикалық конструкция, рекомбинантты ақуыз. 


\section{ПОЛУЧЕНИЕ РЕКОМБИНАНТНЫХ ВНЕКЛЕТОЧНЫХ ФРАГМЕНТОВ РЕЦЕПТОРА GPR161}

Канаев Д.Б., Муканов К.К., Әдіш Ж., Тохтарова Л., Жумабекова С., Інірбай Б., Турсунов К.А., Раманкулов Е.М., Мукантаев К.Н.

Национальный центр биотехнологии

13/5, Кургальжсинское шоссе, Нур-Султан, 010000, Казахстан

lii@biocenter.kz.

\section{АБСТРАКТ}

GPR161 является рецептором семейства GPCR и идентифицирован как прогностический биомаркер для тройного негативного рака молочной железы (TNBC). TNBC характеризуется отсутствием экспрессии рецептора эстрогена (ER), рецептора прогестерона (PR) и рецептора эпидермального фактора роста (Her2), раннего рецидива и плохого прогноза. GPR161 является важным регулятором пролиферации и миграции раковых клеток. Однако рецепторные препараты против GPCR редко используются при лечении рака, несмотря на доказательства участия рецепторов в различных аспектах развития рака. При получении моноклональных антител успех исследования связан с наличием в достаточном количестве чистых антигенных препаратов. В последнее время синтез генов в условиях de novo стал мощным инструментом в биотехнологии. Был описан ряд методов, представляющих собой термодинамически сбалансированные методы, основанные на полимеразной цепной реакции (ПЦР). В данной работе представлены результаты синтеза генов и приготовления рекомбинантного внеклеточного фрагмента рецептора.

Для получения рекомбинантного белка была выбрана область, расположенная вне клеточной мембраны между 4-й и 5-й спиралью рецептора. Была разработана и получена генетическая конструкция на основе вектора pET32, несущего внеклеточный фрагмент человеческого рецептора GPR161. Был получен шттамм Escherichia coli BL21/pET32/TM4-5GPR161, продуцирующий рекомбинантный внеклеточный фрагмент rTM4-5 GPR161. Были определены условия выделения и очистки рекомбинантного белка и изучены его иммуногенные свойства.

Очищенный рекомбинантный белок TM4-5GPR161 по своим иммунологическим характеристикам пригоден для продуцирования штаммов гибридных клеток, продуцирующих моноклональные антитела к рецептору GPR161.

Ключевые слова: GPCR, GPR161, рецептор, рак молочной железы, генетическая конструкция, рекомбинантный белок. 